\title{
Betanidin significantly reduces blood glucose levels in BALB/c mice fed with an atherogenic diet
}

\author{
Agustin Lugo-radillo, ${ }^{\mathrm{a}, \mathrm{b}, *}$ Ivan Delgado-enciso, $^{\mathrm{b}}$ and Elpidio PeÑa-Beltrán ${ }^{\mathrm{c}}$ \\ ${ }^{a}$ Instituto Nacional de Geriatría, Periférico Sur 2767, San Jerónimo Lídice, Magdalena Contreras, 10200 México D.F., México \\ ${ }^{b}$ Facultad de Medicina, Universidad de Colima, Av. Universidad 333, Colonia Las Víboras, 28040 Colima, Colima, México \\ ${ }^{\mathrm{c}}$ Facultad de Ciencias Biológicas y Agropecuarias, Universidad de Colima. Carr. Colima-Manzanillo km 40, 28100 Tecomán, \\ Colima, México
}

Received 9 May 2012; Accepted 15 June 2012

(C) The Author(s) 2012. This article is published with open access at Springerlink.com

\begin{abstract}
Six weeks BALB/c mice were fed with an atherogenic diet for 24 weeks and purified water ad libitum. An experimental group was given betanidin, orally, during the last 40 days of the experiment at a dose of $9.6 \mathrm{mg}$ per mouse per day. Negative controls were fed with standard rodent chow only. Glycemia was measured at the end of the experiment, after overnight fasting. The group treated with betanidin presented a highly significant reduction of $50.94 \%$ compared to positive controls. We conclude that betanidin reduces glycemia in BALB/c mice by an unidentified mechanism.
\end{abstract}

Keywords: betalains, betanidin, blood glucose, hypoglycemiant

\section{Introduction}

Betalains are hydrophilic nitrogenous pigments found in most plants from the order Caryophyllales. These pigments are mainly found in the vacuoles of all their tissues ${ }^{1}$. Betalains confer these plants their yellow, orange, red and violet colours $^{2}$ and are powerful antioxidants ${ }^{3,4}$. In the course of evaluating the antioxidant properties of betanidin', the aglycone of the most common betalain, in the pathophysiology of atherosclerosis, we found that betanidin has an effect in the blood glucose levels in BALB/c mice fed with an atherogenic diet.

\section{Results and Discussion}

Betanidin treatment produced a $50.94 \%$ reduction in the glycemia of mice as compared to the mean from the positive control group (Table 1). This reduction was highly significant $(\mathrm{p}<0.00001)$ compared to both control groups (Figure 1). There were not significant differences between positive and negative controls.

The hypoglycemic effect observed for betanidin we describe here has not been reported before. There are also not reports of any effect of betalains in the insulin or glucose tolerance. As with other betalains ${ }^{3,6-9}$, the main biological action of betanidin known to date in animal biomolecules is its antioxidant capacity ${ }^{10}$. Betalains have also been shown to

*To whom correspondence should be addressed. E-mail:
alugor@hotmail.com

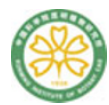

Table 1. Means of glycemia and SEM of the three experimental groups

\begin{tabular}{|c|c|c|c|}
\hline & Positive control & Betanidin & Negative control \\
\hline Glycemia & $170.15 \mathrm{mg} / \mathrm{dl}$ & $86.67 \mathrm{mg} / \mathrm{dl}$ & $170.13 \mathrm{mg} / \mathrm{dl}$ \\
\hline SEM & 4.91 & 5.02 & 6.56 \\
\hline
\end{tabular}

induce the expression of quinone reductases ${ }^{11}$, to inhibit the expression of ICAM-1 ${ }^{12}$ and to decrease the DNA methyl transferase activity ${ }^{13}$. However, none of the effects mentioned can directly explain the hypoglycemic effect observed. Unfortunately, we could not measure glucose or insulin tolerance or levels of expression of the second; therefore, it is not possible to determine if these two factors suffer changes with the administration of betanidin. Moreover, we can only determine that betanidin produce a hypoglycemic effect but it is not possible with the available information to determine if it has also an anti-hyperglycemic effect. We did not quantify the hypoglycemic effect with different doses of betanidin nor the presence of this effect in other betalains. In respect to the latter, since the antioxidant capacity and the other effects mentioned before are considered to be present in all betalains ${ }^{3,4,6-8,10-12,14,15}$, it may be possible that the hypoglycemic effect is present in all this group of molecules; further studies will determine if this is the case.

\section{Experimental Section}

Animals. Six weeks inbred BALB/c mice (Harlan Laboratories, Indiana, USA) were randomly assigned into cages ( $\mathrm{n}=5$ per cage), acclimatized for 2 weeks in a 12 hours 


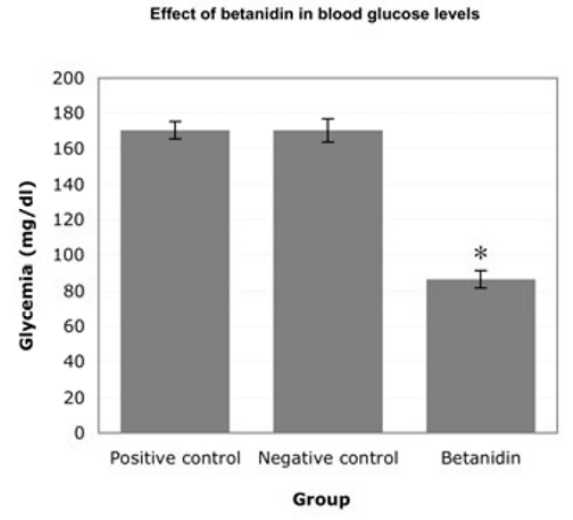

Figure 1. Effect of betanidin in blood glucose levels. Oral administration of betanidin produced a significant reduction of around $50 \%$ in the blood glucose levels in BALB/c mice. $*=\mathrm{p}<0.00001$

ligth/12 hours darkness cycle. They were fed with a Teklad Global Diet 2018S (Harlan Laboratories, Indiana, USA) and purified water ad libitum. At the start of the experiment, the diet of the animals was changed to an atherogenic rodent diet TD.02028 (15.5\% $\mathrm{kcal} / \mathrm{kcal}$ protein; $41.9 \% \mathrm{kcal} / \mathrm{kcal}$ carbohydrates; $42.6 \% \mathrm{kcal} / \mathrm{kcal}$ fat) (Harlan Laboratories, Indiana, USA). The negative group $(n=16)$ continued to be fed with the Teklad Global Diet 2018S. Positive control $(\mathrm{n}=$ $13)$ and betanidin $(n=12)$ groups continued with the atherogenic diet for 24 weeks. During the last 40 days of the experiment, betanidin was given orally to the betanidin group at a dose of $9.6 \mathrm{mg}$ per mouse per day. After an overnight fasting (water was not suspended), decapitation was performed as part of a parallel experimental protocol. The findings here described resulted as parallel data from a bigger research project evaluating the effect of betanidin in dyslipidemia. All animal procedures were approved by the Bioethics Committee from the University of Colima and conducted in accordance with the Guide for the Care and Use of Laboratory Animals published by the US National Institutes of Health.

Betanidin Obtainment. Betanin extraction and purification Fresh red-purple pitaya fruits (Hylocereus ocamponis) were purchased from a commercial plantation in Jalisco (Mexico). Upon arrival of fruits, they were washed and peeled by hand. Skins were discarded and the fruit flesh was macerated in a blender until being completely homogenized. For pigment extraction, 1 part of this sample was shaken with 2 parts of solvent for 5 minutes and allowed to stand for $15 \mathrm{~min}$; solvents used were $80 \%$ acetone, $80 \%$ methanol and ultra purified water. After, the mixture was filtrated through a nylon cloth and centrifuged at $3500 \mathrm{rpm}$ for $15 \mathrm{~min}$. Afterwards, the supernatant was filtered through YM-10 membranes (Millipore) to remove proteins, and the filtrate was used for pigment analysis and further purification. All was performed at room temperature. Betanin was purified by FPLC and confirmed by HPLC as performed by Gandía-Herrero, et $a l^{5}$. Afterwards, it was aliquoted and kept at $-80{ }^{\circ} \mathrm{C}$ in the dark until use.

Betanidin synthesis An enzymatic hydrolysis of purified betanin with $\beta$-glucosidase was performed as stated by
Gandía-Herrero, et $a l^{5}$. Transformation was complete according to HPLC analysis.

Blood Glucose Levels. A OneTouch Ultra test strip (LifeScan, California, USA) was filled with a drop of blood immediately after euthanasia. Blood glucose levels were measured using a OneTouch UltraMini meter (LifeScan, California, USA) and the results were expressed in $\mathrm{mg} / \mathrm{dl}$. Calculations and graphs were carried out in the Microsoft Excel software (Microsoft Corporation, Washington, USA).

Statistical Analysis. Data represent mean \pm SEM. One-way ANOVA test was used as a measure of significance. Differences with $p$ values of less than 0.05 were considered statistically significant. Statistical analyses were carried out in the Microsoft Excel software (Microsoft Corporation, Washington, USA).

\section{Electronic Supplementary Material}

Supplementary material is available in the online version of this article at http://dx.doi.org/ 10.1007/s13659-012-0034-z and is accessible for authorized users.

Open Access This article is distributed under the terms of the Creative Commons Attribution License which permits any use, distribution, and reproduction in any medium, provided the original author(s) and source are credited.

\section{References}

[1] Gandia-Herrero, F.; Escribano, J.; Garcia-Carmona, F. Planta 2005, 222, 586-593.

[2] Azeredo, H. M. C. Int. J. Food Sci. Technol. 2009, 44, 2365-2376.

[3] Butera, D.; Tesoriere, L.; Di Gaudio, F.; Bongiorno, A.; Allegra, M.; Pintaudi, A. M.; Kohen, R.; Livrea, M. A. J. Agric. Food Chem. 2002, 50, 6895-6901.

[4] Cai, Y.; Sun, M.; Corke. H. J. Agric. Food Chem. 2003, 51, 22882294.

[5] Gandia-Herrero, F.; Escribano, J.; Garcia-Carmona, F. J. Agric. Food Chem. 2007, 55, 1546-1551.

[6] Tesoriere, L.; Butera, D.; D'Arpa, D.; Di Gaudio, F.; Allegra, M.; Gentile, C.; Livrea, M. A. Free Radic. Res. 2003, 37, 689-696.

[7] Tesoriere, L.; Allegra, M.; Butera, D.; Livrea, M. A. Am. J. Clin. Nutr. 2004, 80, 941-945.

[8] Allegra, M.; Furtmuller, P. G.; Jantschko, W.; Zederbauer, M.; Tesoriere, L.; Livrea, M. A.; Obinger, C. Biochem. Biophys. Res. Commun. 2005, 332, 837-844.

[9] Allegra, M.; Tesoriere, L.; Livrea, M. A. Free Radic. Res. 2007, $41,335-341$

[10] Kanner, J.; Harel, S.; Granit, R. J. Agric. Food Chem. 2001, 49 $5178-5185$.

[11] Lee, C. H.; Wettasinghe, M.; Bolling, B. W.; Ji, L. L.; Parkin, K. L. Nutr. Cancer 2005, 53, 91-103.

[12] Gentile, C.; Tesoriere, L.; Allegra, M.; Livrea, M. A.; D'Alessio, P. Ann. NY Acad. Sci. 2004, 1028, 481-486.

[13] Paluszczak, J.; Krajka-Kuzniak, V.; Baer-Dubowska, W. Toxicol. Lett. 2010, 192, 119-125.

[14] Wettasinghe, M.; Bolling, B.; Plhak, L.; Xiao, H.; Parkin, K. J. Agric. Food Chem. 2002, 50, 6704-6709.

[15] Tesoriere, L.; Allegra, M.; Gentile, C.; Livrea, M. A. Free Radic. Res. 2009, 43, 706-717.

\section{照 Springer}

